\title{
Kartellbußen aus rechtlicher und ökonomischer Sicht
} Der Problemfall der Zementkartelle

[Cartel Fines from a Legal and an Economic Standpoint. The Problematic Case of the Cement Cartels.]

Published in German.

Fines are the means chosen by cartel authorities around the world to combat hard-core cartels. The real impact of cartel fines

ROGER PIERENKEMPER

Kartellbußen aus rechtlicher und ökonomischer Sicht

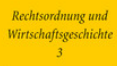

Mohr Siebeck

2012. XVII, 270 pages. ROWG 3

ISBN 978-3-16-151916-1

cloth $104,00 €$

ISBN 978-3-16-160608-3

eBook PDF 104,00 € is however still unknown. The prime example of hard-core cartels are the cartels in the cement industry. Using the cement cartels as an example, Roger Pierenkemper studies the effects that cartel fines actually have.

Roger Pierenkemper Geboren 1982; Studium der Rechtswissenschaft in Berlin, Aarhus, und Marburg; seit 2009 Wissenschaftlicher Mitarbeiter am Lehrstuhl für Bürgerliches Recht an der Universität Marburg; 2012 Promotion; derzeit Rechtsreferendar am LG Marburg.

\section{Order now:}

https://www.mohrsiebeck.com/en/book/kartellbussen-aus-rechtlicher-und-oekonomischer-sicht-9783161519161?no_cache=1 order@mohrsiebeck.com

Phone: +49 (0)7071-923-17

Fax: +49 (0)7071-51104 